$$
\begin{aligned}
& \text { معرفى اكتينوباكترهاى مولد اكزويليمرهاى داراى خاصيت ضدميكربى از خاكهاى ايران } \\
& \text { سوگَل تواناييان'، جواد حامدى ' و ستاره حقيقت }
\end{aligned}
$$

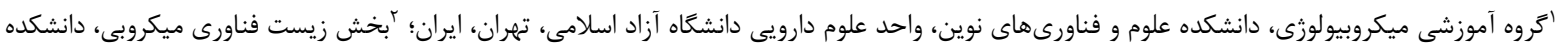

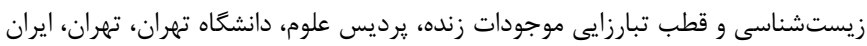

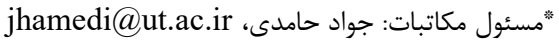

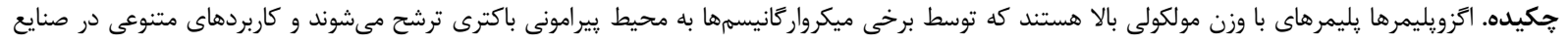

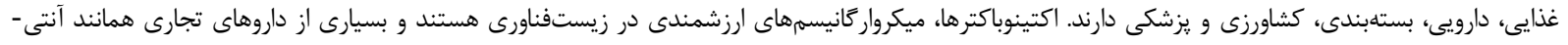

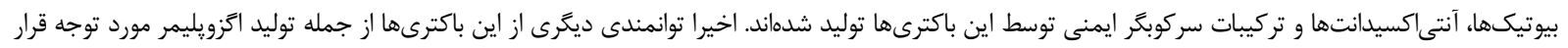

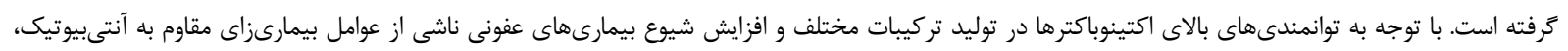

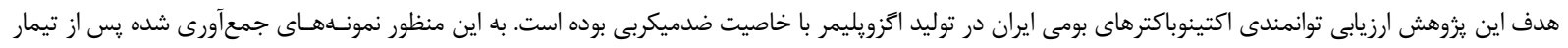

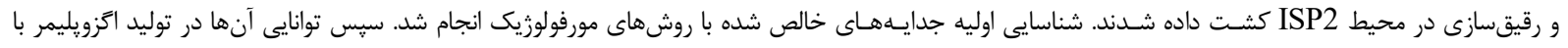

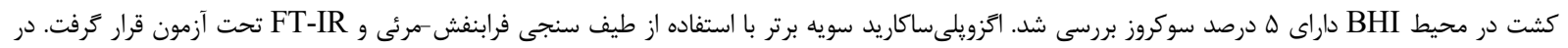

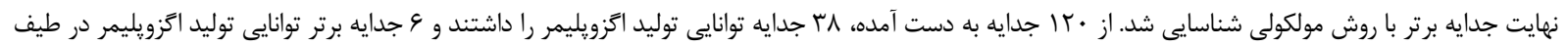

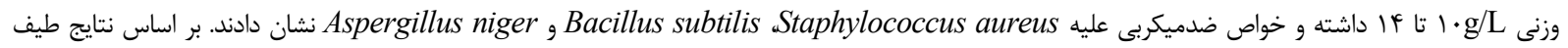

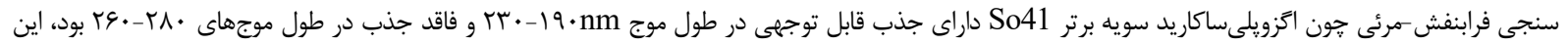

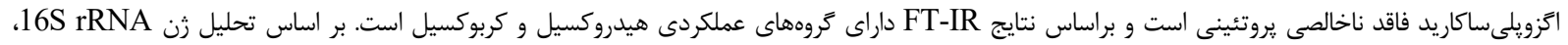

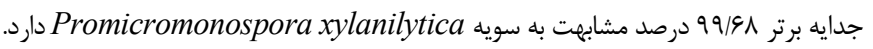

$$
\text { وازمهاى كليدى. اكتينوباكترهاى كمياب، يروميكرومونوسيورا، يلىساكاريد، فعاليت ضدباكترى، فعاليت ضدقارج }
$$

\title{
Introducing antimicrobial exopolymer-producing actinobacteria from soils of Iran
}

\author{
Sogol Tavanaeian ${ }^{1}$, Javad Hamedi ${ }^{2}$ \& Setareh Haghighat ${ }^{1}$ \\ ${ }^{1}$ Department of Microbiology, Faculty of Advanced Sciences and Technologies, Pharmaceutical Sciences Branch, \\ Islamic Azad University, Tehran, Iran; ${ }^{2}$ Department of Microbial Biotechnology, School of Biology and Center of \\ Excellence in Phylogeny of Living Organisms, College of Science, University of Tehran, Tehran, Iran \\ Correspondent author: Javad Hamedi, jhamedi@ut.ac.ir
}

\begin{abstract}
Exopolymers (EPS) are high-molecular-weight polymers secreted by some micro-organisms and have several applications in food, pharmaceutical, packaging and agricultural industries, as well as medicine. Actinobacteria are valuable bacteria in biotechnology and many commercial drugs such as antibiotics, antioxidants and immune-suppressant agents are derived from Actinobacteria. Recently, their other capabilities such as exopolymer production have been taken into consideration. Due to the high potential of actinobacteria in producing various compounds and increased prevalence of infections by antibiotic-resistant pathogens, the aim of the present study was to evaluate the potential of isolated Actinobacteria from various locations of Iran to produce EPS with antimicrobial activity. Appropriate dilutions of the samples were, therefore, cultured in ISP2 medium after treatment. The isolates were primarily identified by morphological tests. Then, their ability to produce EPS was investigated in BHI medium with 5\% sucrose. The exopolymers of the most efficient strain were analyzed by UV-visible spectroscopy and FT-IR. Finally, the most efficient isolate was molecularly identified. Of the 120 isolates, 38 were able to produce EPS, and six had significant capability of producing EPS (10-14 g/L) and showed antibiotic activity against Staphylococcus aureus, Bacillus subtilis and Aspergillus niger. The EPS of the strain So49 had high
\end{abstract}


absorbance in 190-230 nm, but did not have absorbance in 260-280 nm. Therefore, it does not have any protein impurity. The EPS has hydroxyl and carboxyl functional groups, according to FT-IR analysis. 16S rRNA gene analysis showed that the most efficient isolate had $99.68 \%$ similarity to Promicromonospora xylanilytica.

Keywords: antibacterial activity, antifungal activity, polysaccharide, Promicromonospora, rare actinobacteria

با كاربرد در يوشش زخم يا داربستهايى براى مهندسى بافت از

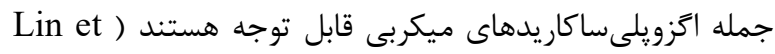
al., 2013; Kim et al., 2014 كنترل شده دارو، دريجه اى نوين را براى كاربردهاى دارويى براى

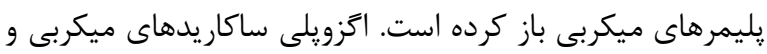

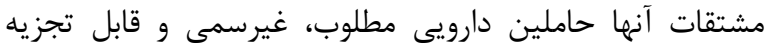

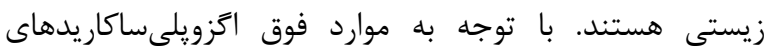

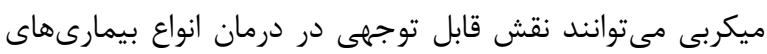
متابوليك و سرطانها ايفا كنند (Moscovici, 2015). با اين وجود بخشى از مركى و مير ايجاد شده به ويزه در

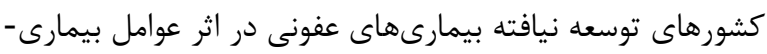

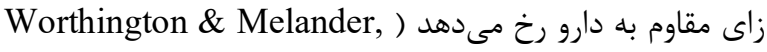

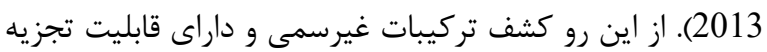

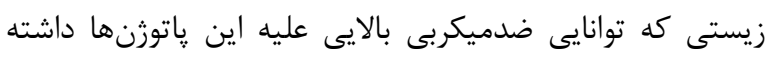

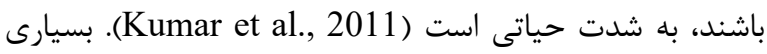

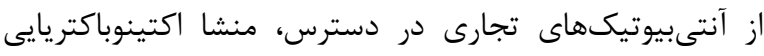

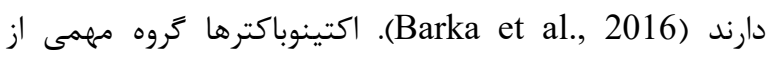
باكترىهاى كرم مثبت با درصد كوانين و سيتوزين بالا در زنوم آنوم خود بوده و بسيارى از آنها قادر به توليد ميسيليومهاى صاف صاف و ورين يا مواج با قطر حدود يك ميكرومتر هستند ( Arifuzzaman et

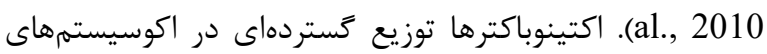

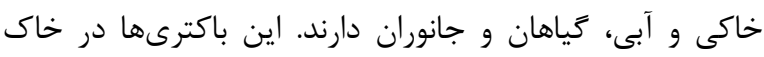

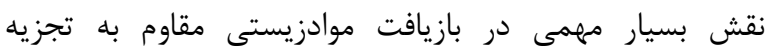

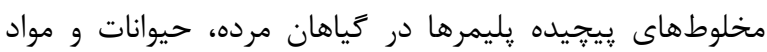

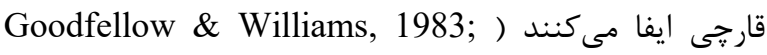
Stach \& Bull 2005

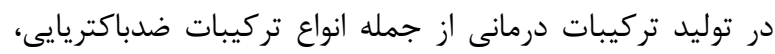
ضدقارجى و ضدويروسى نشان دادهاند، احتمال يافتن اكتينوباكتر

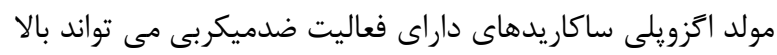

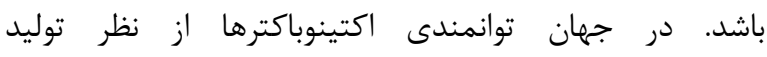

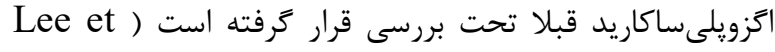
al., 2010; wu et al., 2010; Manivasagan et al., 2014. با اين وجود توانمندى اكتينوباكترهاى بومى ايران از

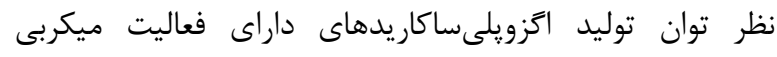

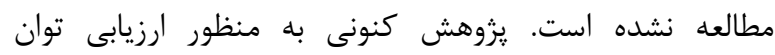

يليمرهاى ميكربى به يليمرهاى درون سلولى، يليمرهاى

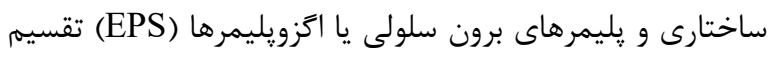
مىشوند (Suresh Kumar et al., 2007). اكزويليمرها (EPS)

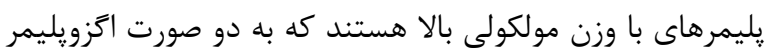

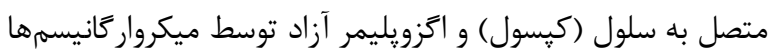
به محيط اطراف ترشح مىشوند (Vijayabaskar et al., 2011).

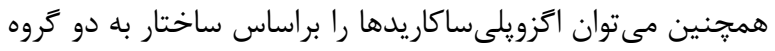

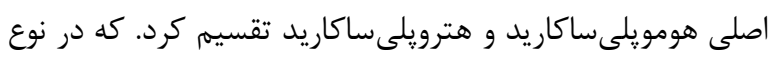

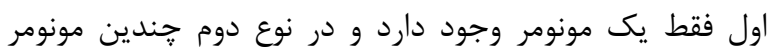

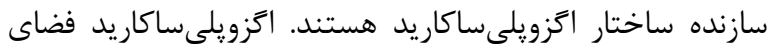

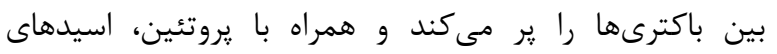

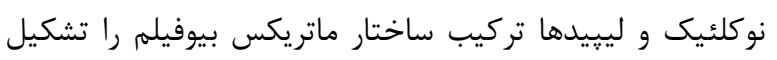

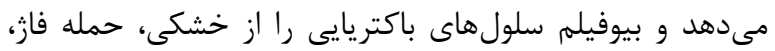
تركيبات ضدميكربى، تنش اسمزى و شكار شدن توسط تكىياخته

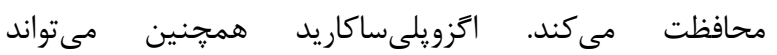

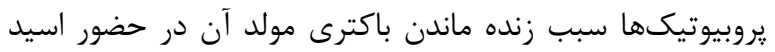
معده و نمكهاى صفراوى شود (Ciszek-Lenda, 2011).

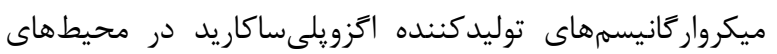
مختلف يافت مىشوند. محيطهاى داراى نسبت كربن به نيتروزن

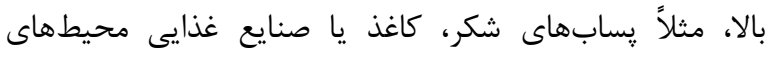

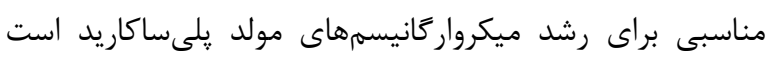
.(Suresh Kumar et al., 2007) اتزويلىساكاريدهاى ميكربى از اواسط قرن بيستم كاربردهاى

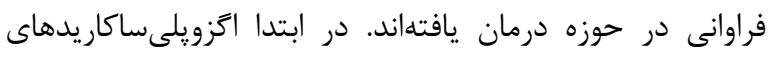

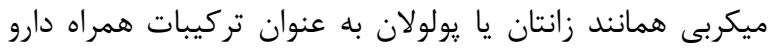
مورد استفاده قرار كرفتند (excipients)

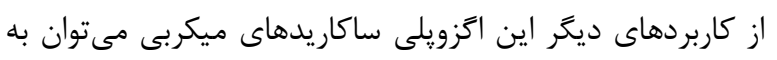

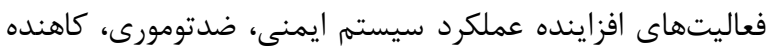

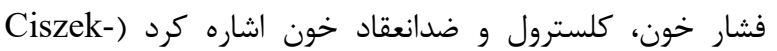
(Lenda, 2011; Hidalgo-Cantabrana et al., 2014 آلزينات ميكربى با فعاليت ضدرفلاكس، يركنندهاى دندانى يا

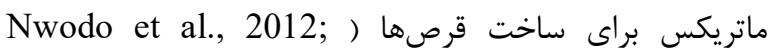

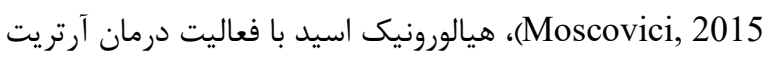
و بهبود دهندكى زخم (Kim et al., 2014) و سلولز باكتريايى 
ميلىليتر محيط BHI مايع + ه درصد سوكروز تلقيح شدند.

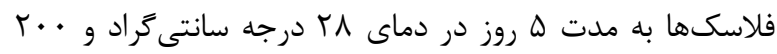

دور در دقيقه كرماگذارى شدند (Khalil et al., 2018).

\section{استخراج اكزويليمر}

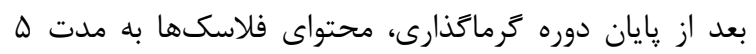

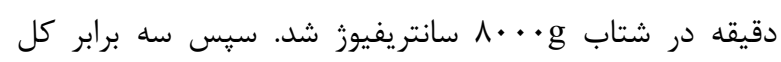

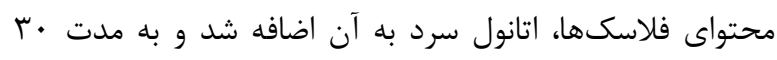

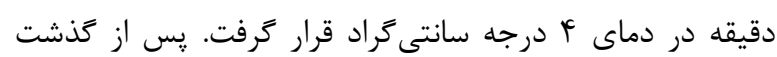

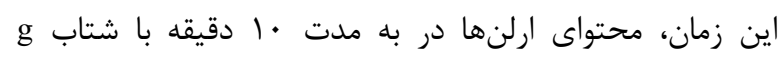

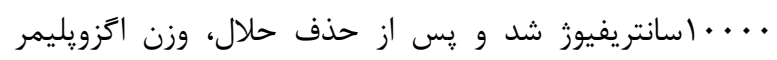

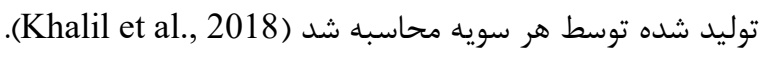

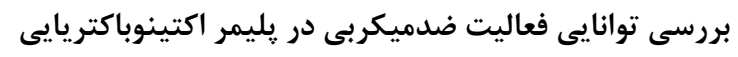

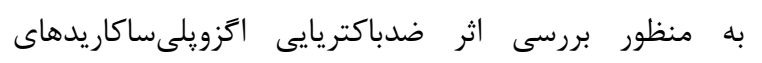

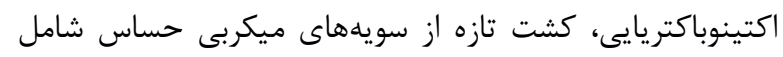
DSMZ 23622 , Escherichia coli ATCC 8739 Staphylococcus aureus

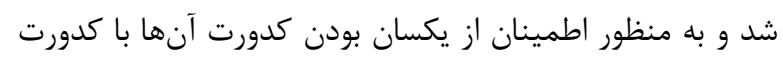

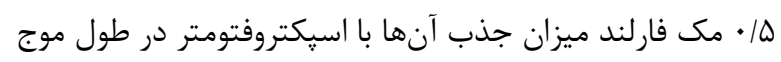

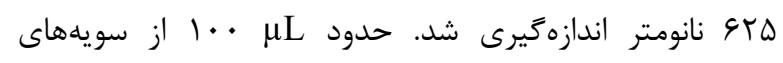

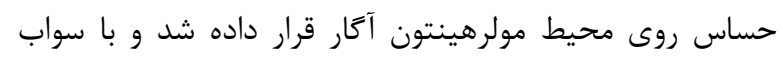

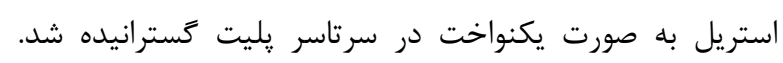

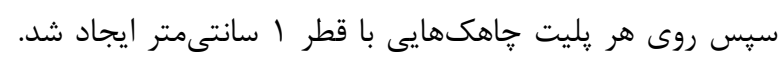

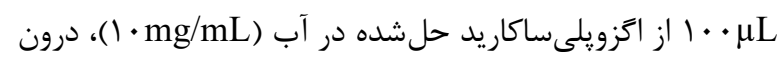

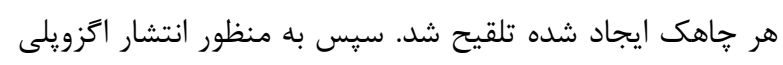

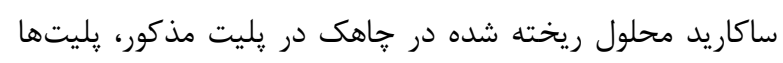

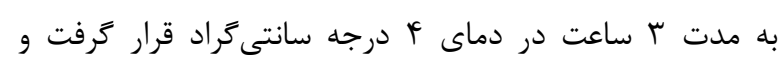

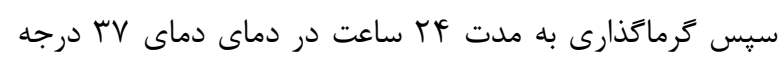

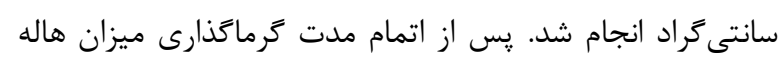

عدم رشد توسط كوليس اندازهيرى شد (Jorgensen, 1993).

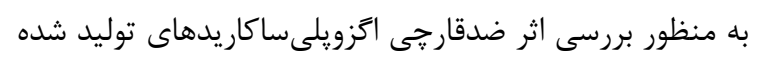
توسط جدايههاى اكتينوباكتريايى بر روى ابتدا غلظت مورد نظر از اتزويلىساكاريدهاى مورد رون

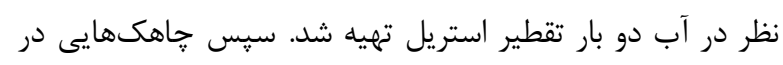

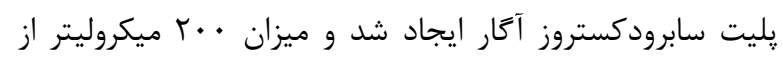

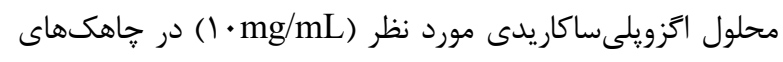

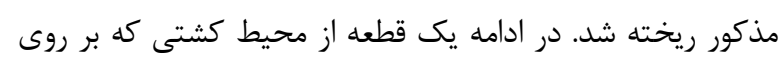

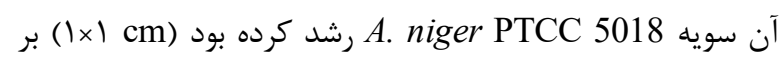

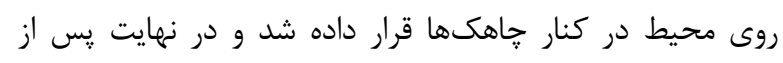

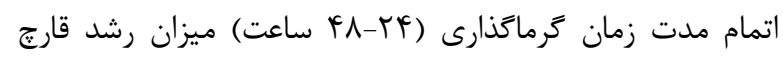

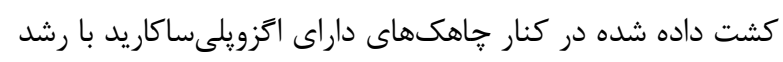

اكتينوباكترهاى موجود در ايران از نظر توليد اكزويلىساكاريد كه فعاليت ضدميكربى داشته باشند، انجام شده است.

\section{مواد و روش ها}

نمونههاى تحت بررسى از مناطق مختلف شامل خاكهاى

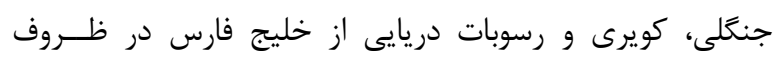

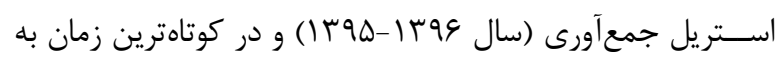

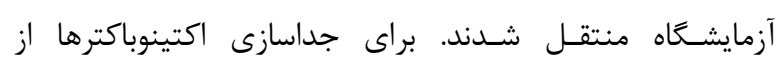

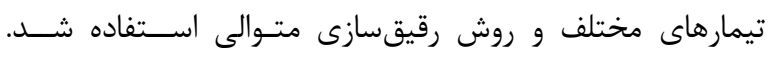

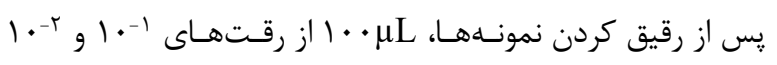

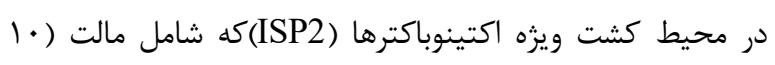

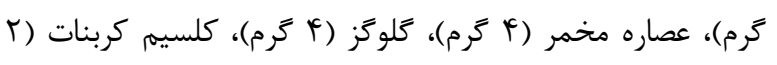

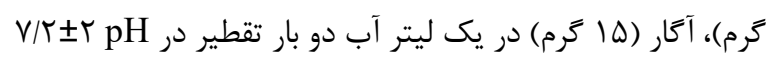

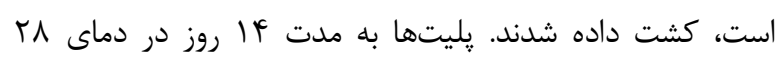
درجه سانتى

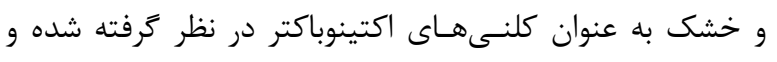

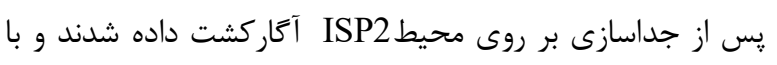

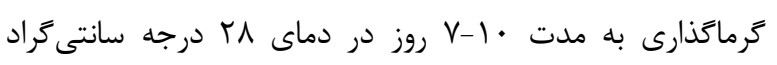

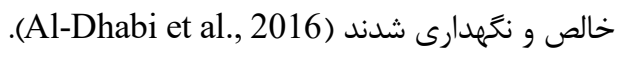

تعيين ايزومر دى آمينو پايمليك اسيد (DAP)

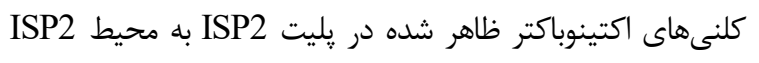

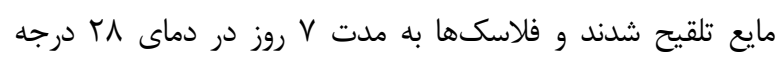

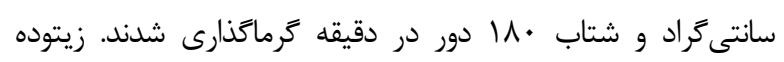

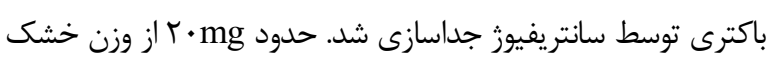

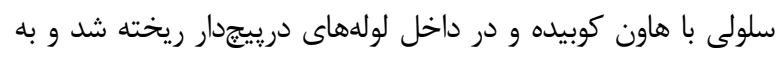

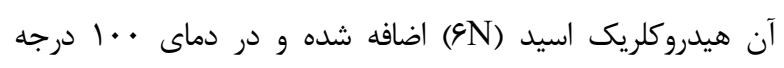

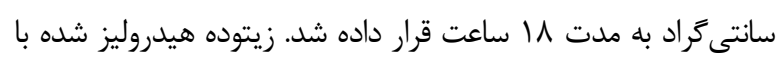

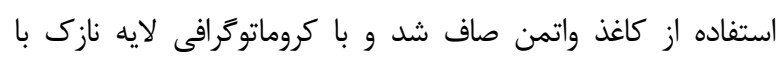

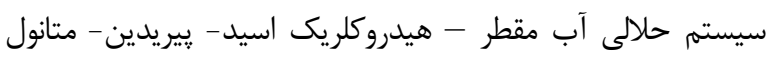

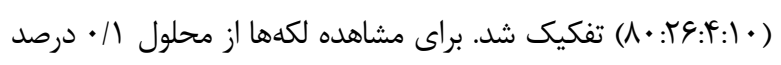

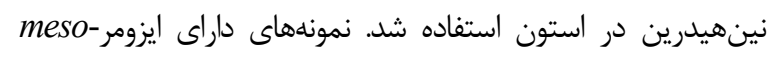

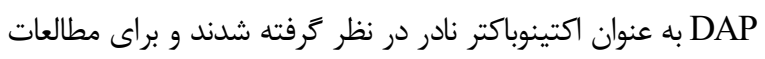
فراتر انتخاب شدند.

\section{غربالكرى اكتينوباكترهاى مولد اكزويليمابل}

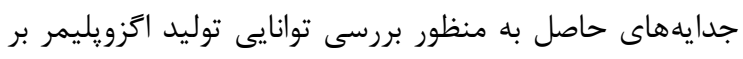

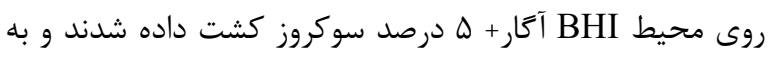

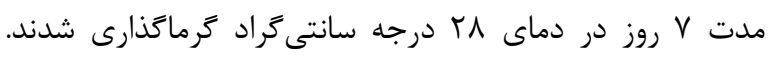

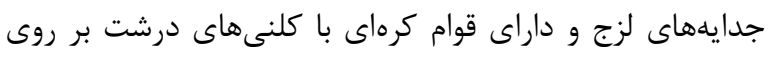

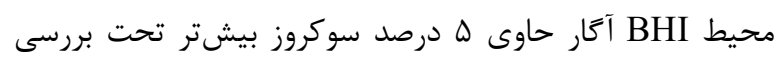

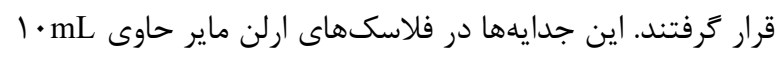


مشاهده شده روى زل آكارز براى توالىيابى به شركت ماكروزن كره جنوبى ارسال شدند (Kumar et al., 2010).

نتنايج از . .1 نمونه بررسى شده • r| جدايه با كلنى و ظاهر شبيه به

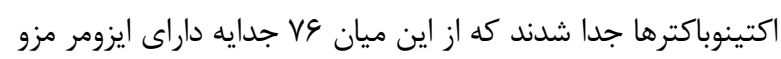
در تست DAP بودند. همان

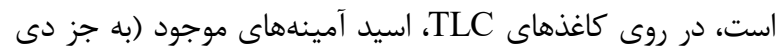

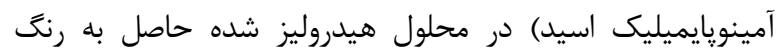

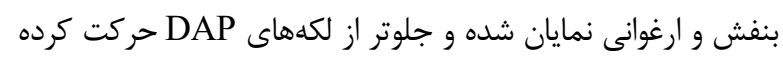

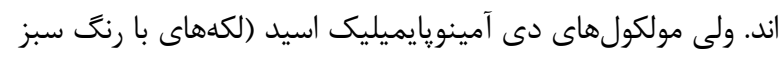

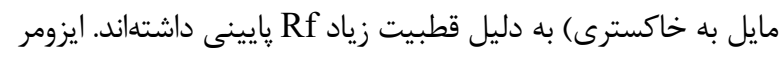

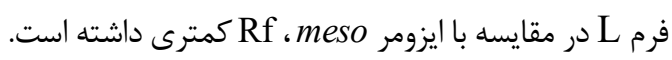
بررسى توان توليد اتزويلهىساكاريد

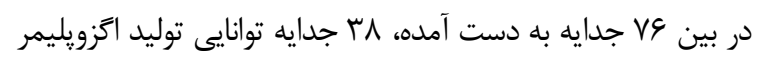

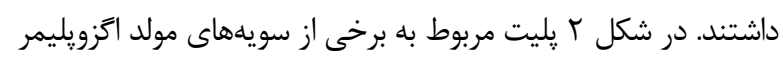

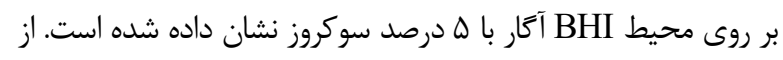

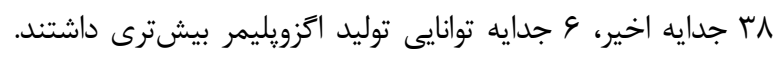

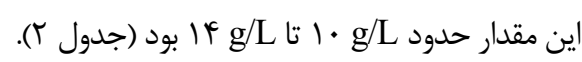

ارزيابى فعاليت ضدميكربى اتزويليمرها نتيجه ارزيابى فعاليت ضدميكربى و ضدقارجى إيكى اتزويليمرهاى

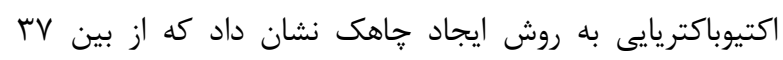

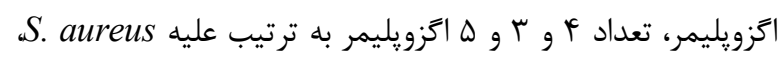
A. niger و E. coli

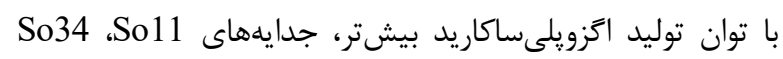

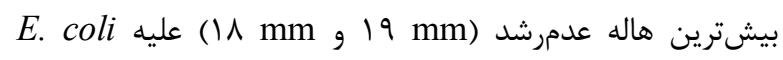

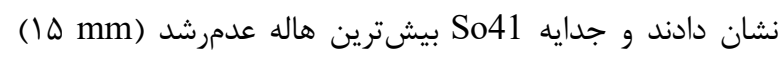
عليه A. niger نشان داد. تحليل ساختارى اكزو يلىساكاريد سويه منتخب داري

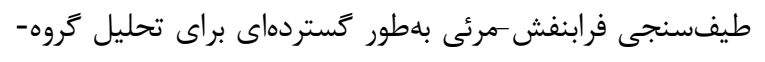

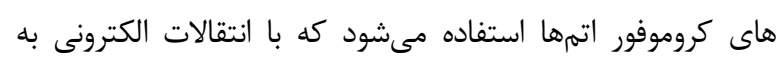

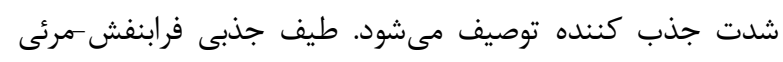

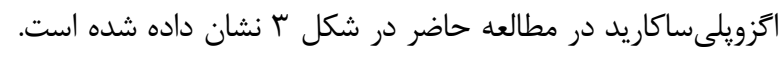

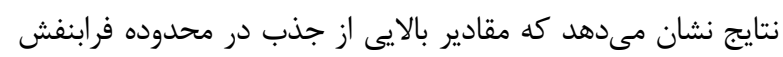

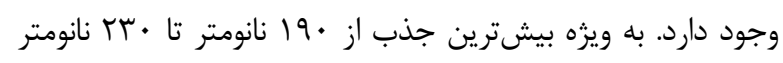

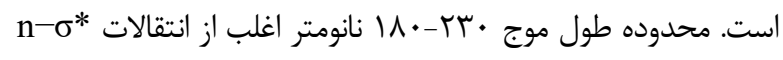

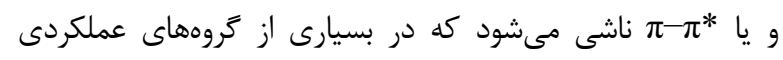

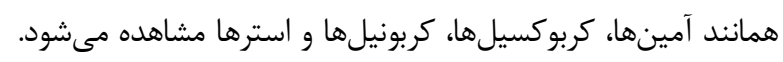

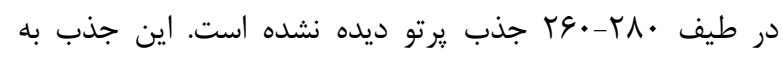

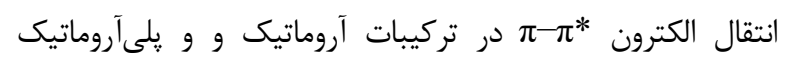

قارج كشت داده شده در كنار جاهك داراى آب دو بار تقطير استريل (شاهد) مقايسه شد. بررسى ويزگى هاى ساختارى اگزويلى ساكاريد سويه منتخب به منظور انجام تحليلهاى طيف سنجى فرابنفش -مرئى و وائ تبديل فوريه فروسرخ نمونه اگزويلىساكاريد (mg • () استخراجشده از سويه منتخب در ه ميلى ليتر آب دوبار تقطير حل شد. طيف سنجى فرابنفش -مرئى

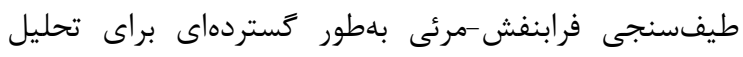

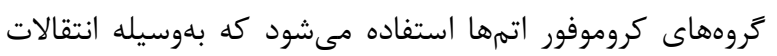

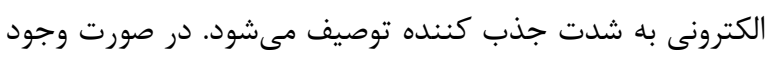

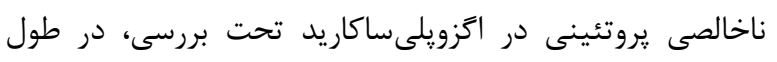

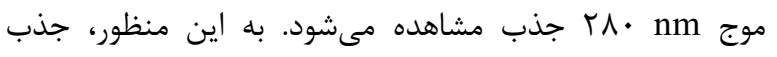

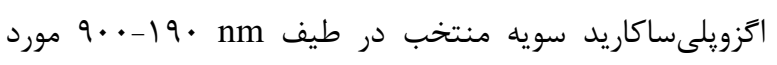
خوانش قرار كرفت (Castellane et al., 2015). تحليل گروههاى عملكردى طيف فروسرخ به دست آمده از ولمى تراكاريد خالص طيف

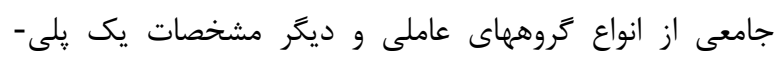

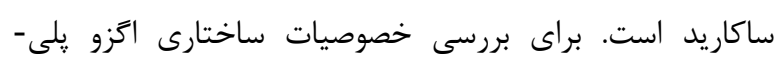

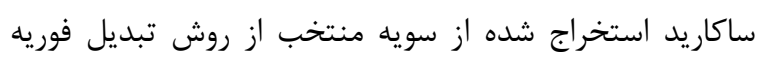

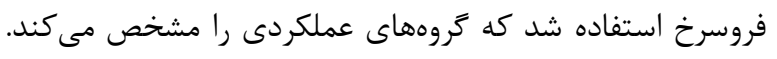

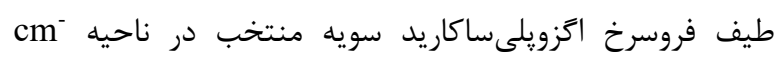

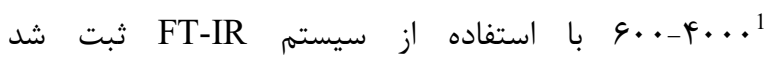
(Kanamarlapudi \& Muddada, 2017)

16SrRNA شناسايى مولكولى و تعيين ترادف زن به منظور استخراج DNA، جدايههاى مورد نظر در فلاسكهاى تردي

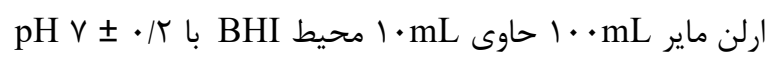

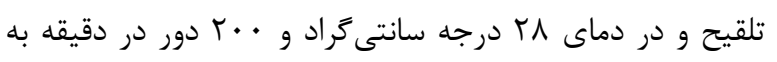
مدت آلود

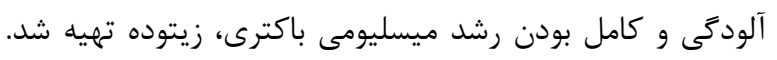

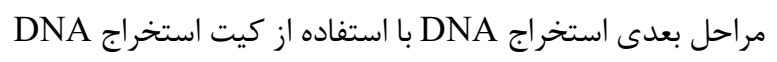

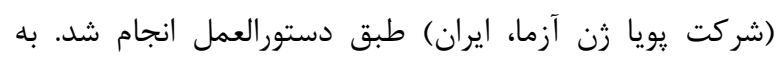

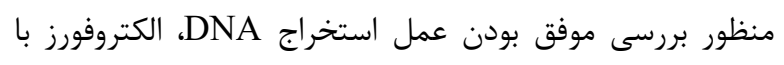

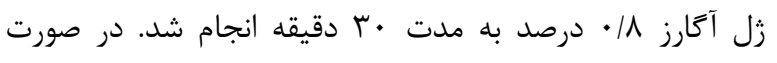

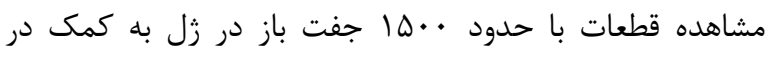

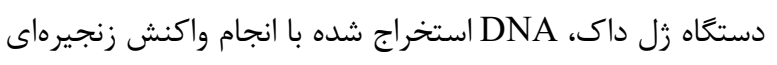

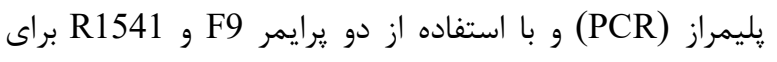

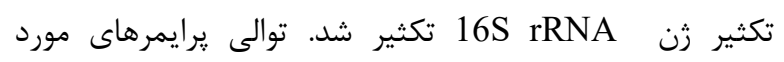

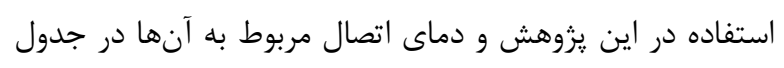

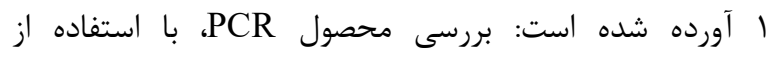

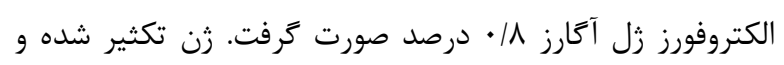




$$
\text { جدول 1- برايمرهاى به كار رفته براى تكثير ثن 16SrRNA. }
$$

Table 1. The primers used for amplification of 16SrRNA gene.

\begin{tabular}{ccc}
\hline Primer name & Sequences & Tm $\left({ }^{\circ} \mathrm{C}\right)$ \\
\hline $9 \mathrm{~F}$ & 5'- AAG AGT TTG ATC ATG GCT CAG -3' & 60 \\
$1541 \mathrm{R}$ & 5'- AGG AGG TGA TCC ACC CGC A -3' & 60 \\
\hline
\end{tabular}

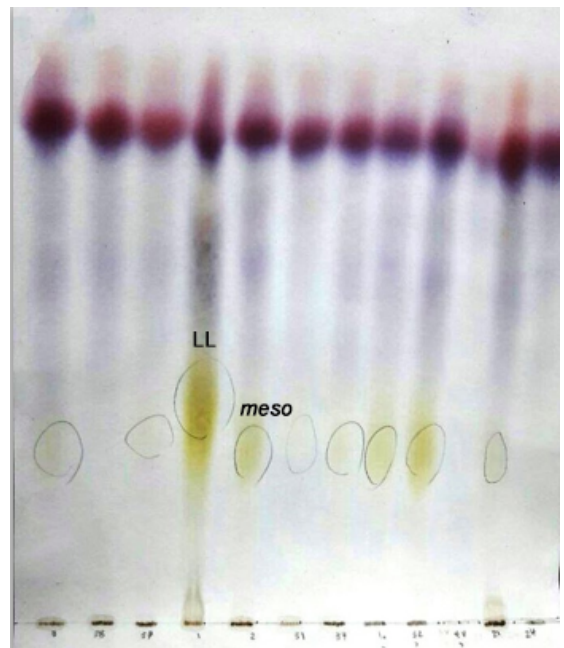

شكل ا- پيليت TLC براى تحليل تشخيص نوع ايزومردى آمينويايميليك اسيد در جدايههاى اكتينوباكتر. ايزومر نوع Lبك تر از ايزومر نوع meso است. ديكر

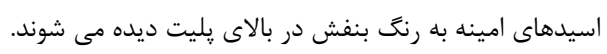

Fig. 1. TLC plate for detection of diaminopimelic acid isomer in the actinobacterial isolates. $L$ type isomer is lighter than meso type isomer. Other amino acids are observed with the purple color on the top of TLC plate.

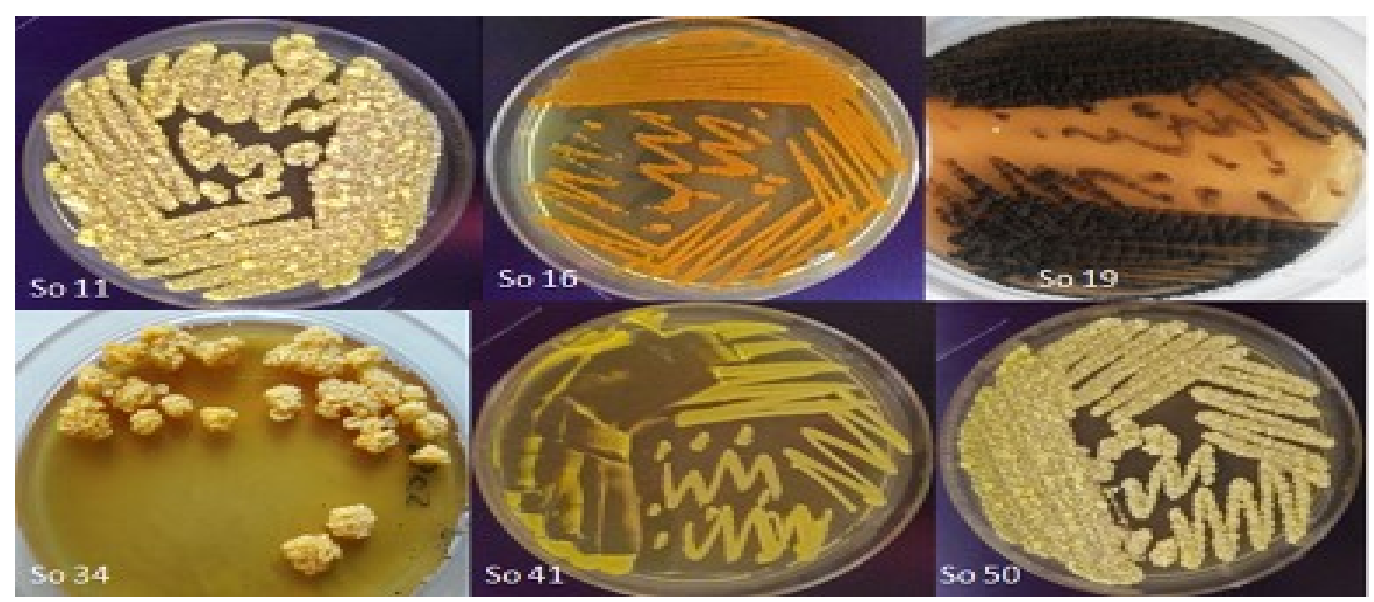

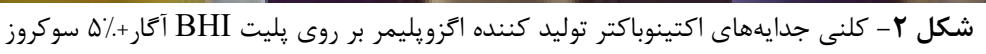

Fig. 2. Colonies of exopolymer-producing actinobacterial isolates on BHI plate $+5 \%$ sucrose

\begin{tabular}{|c|c|}
\hline شماره سويه & ميزان اكزويلىساكاريد توليد شده (g/L) \\
\hline So11 & $1 \% / r$ \\
\hline So16 & $11 / 4$ \\
\hline So19 & $1 \cdot 11$ \\
\hline So34 & $1 \% / \Delta$ \\
\hline So41 & $\mid \% /$. \\
\hline So50 & $11 / \mathrm{V}$ \\
\hline
\end{tabular}

$$
\text { جدول r- ميزان توليد اگزويليمر در جدايه هاى اكتينوباكتر برتر در محيط BHI + BH سوكروز }
$$

Table 1. Exopolymer-production in more efficient actinobacterial isolates in BHI + 5\% sucrose 
كسترده در اطراف MrYrcm

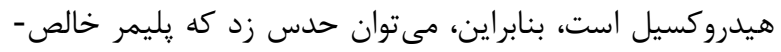

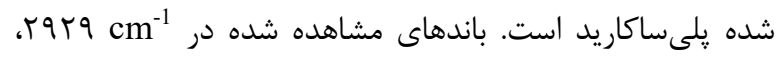

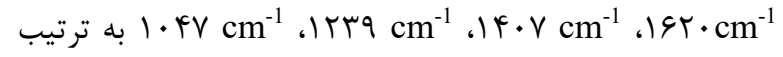

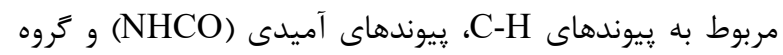

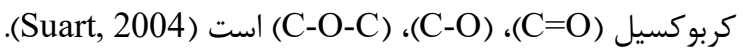

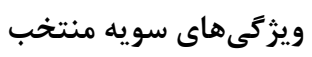

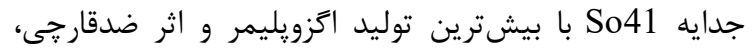

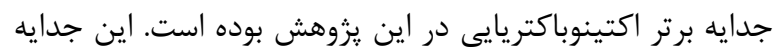

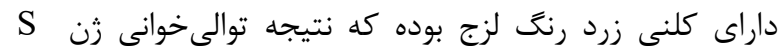
19rRNA سامانه :http://www.ezbiocloud.net/taxonomy) EZ-taxon نشان داد كه 99/91 درصد مشابه با سويه Promicromonospora xylanilytica
مربوط مىشود كه غالباً در مولكولهاى كانجوكه شامل يروتئينها ديده مىشود. بنابراين مى توان نتيجه كرفت كه اتزويلىساكاريد تحت بررسى فاقد ناخالصى يروتئينى است ( Bikova \& .(Treimanis, 2004; Jia et al., 2007 بررسى طيف فروسرخ نيز يكى از روشهاى اطمينان از خلوص

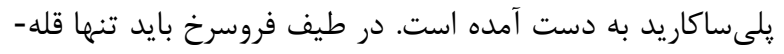

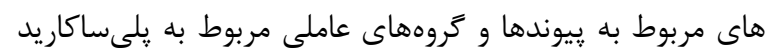

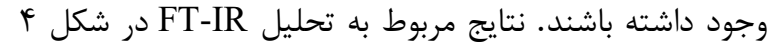

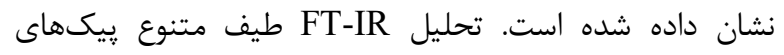

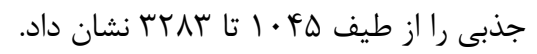

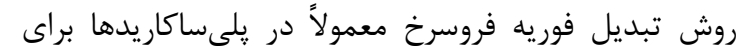
بررسى نوع بيوندهاى كليكوزيدى، نوع مونوساكار يدها و كروههاى

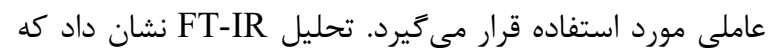
اتزويلىساكاريد تحت بررسى به علت دارا بودن پيیى جذبى

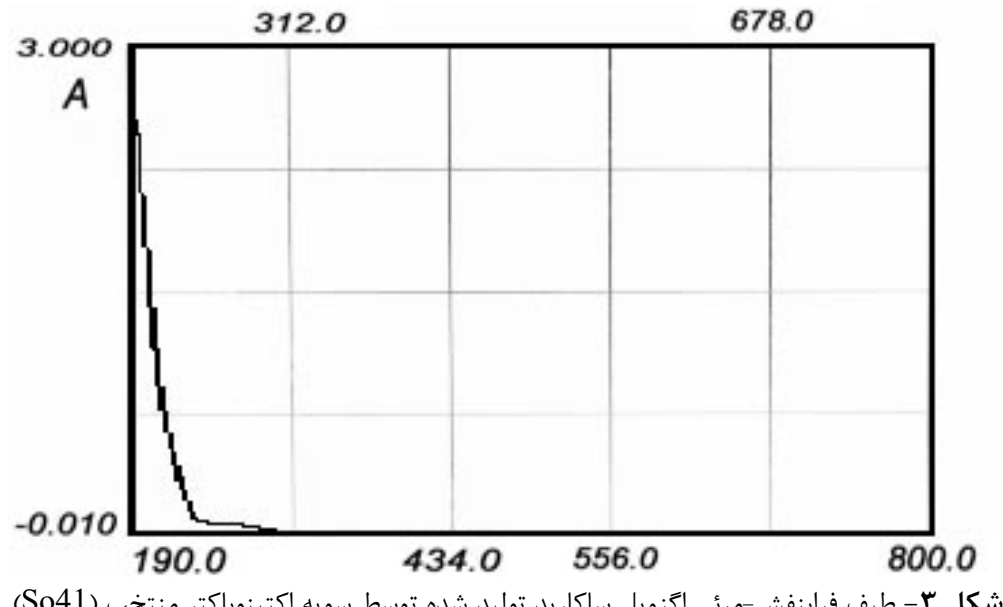

Fig. 3. UV-visible spectrum of exopolysaccharides produced by the selected actinobacterial strain (So41).

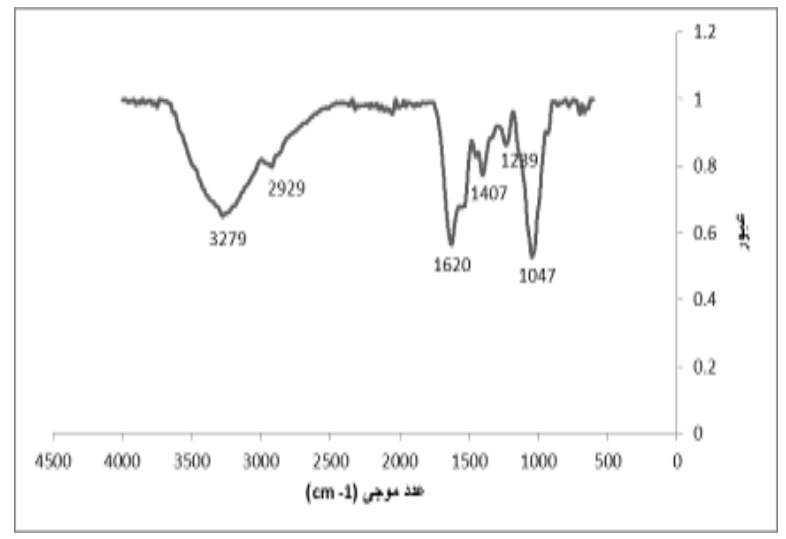

شكل F - طيف FT-IR اتزويلىساكاريد حاصل از اكتينوباكتر سويه So41 from the

Fig. 4. FT-IR spectrum of exopolysaccharide obtained from the actinobacterium strain So41. 


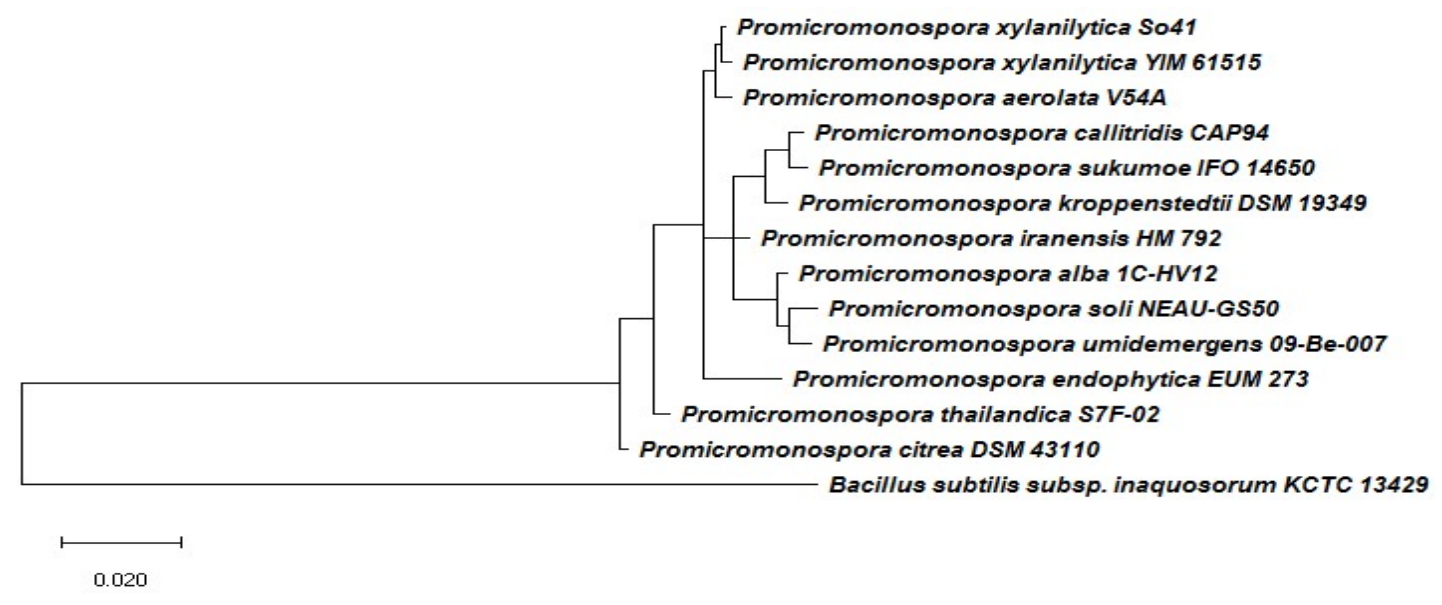

شكل ه- درخت فيلوزنى سويه so41 بر اساس روش بيشترين احتمال.

Fig. 5. Phylogenetic tree of strain so41 and its neighbors by maximum likelihood method

در كنترل شكل گيرى گويجههاى سفيد خون، در درمان آرتريت

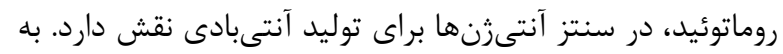

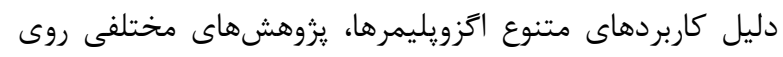
آنها انجام شده است و به همين دليل يافتن ازَويليمرهاى

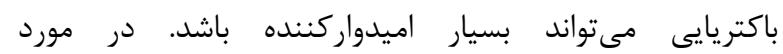

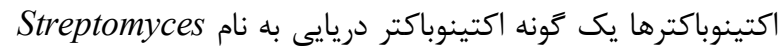
violaceous

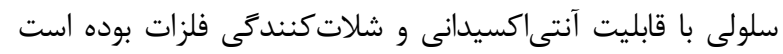
-(Manivasagan et al., 2014)

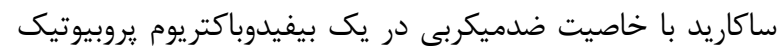
كزارش شده است (Wu et al., 2010).

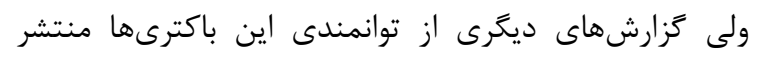
نشده است. اززويلىساكاريد استخراج شده از استارترهاى ماست

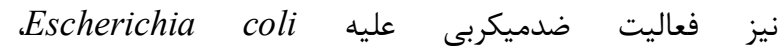
Proteus ،Streptococcus sp. ،Staphylococcus aureus (YV-ID) Candida albicans, spp (Ghalem, 2017)

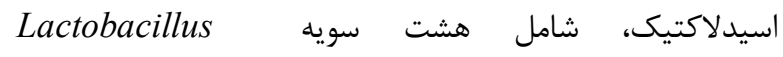
Lefiranofaciens سويه Lactococcus lactis و رينج سويه Lويه Leuconostocs 16S mesenteroides Lactobacillus شناسايى شدند. در اين ميان سويه rRNA kefiranofaciens DN1 گرم در ليتر در محيط MRS تغيير يافته داراى •و گرم گلوكز در ليتر) را توليد كرده است. اين اگزويلىساكاريد فعاليت ضدميكربى عليه Listeria monocytogenes و كريتر) enteritidis

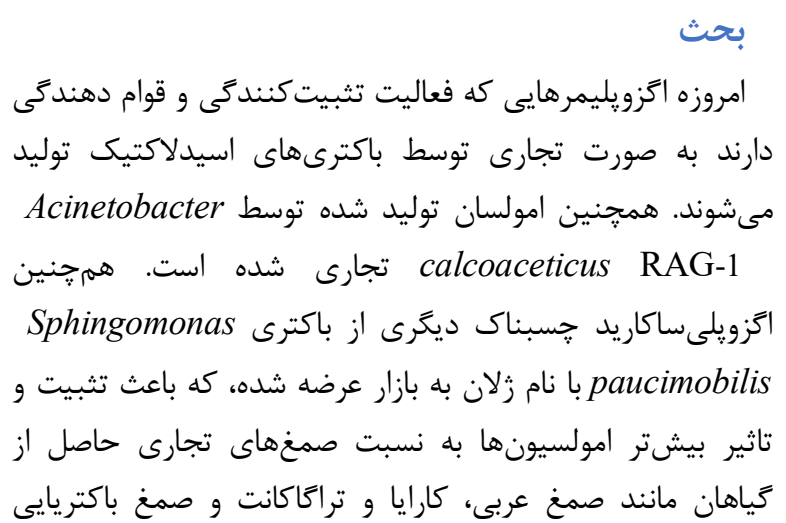

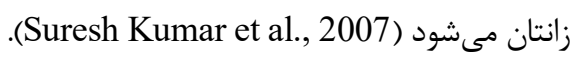

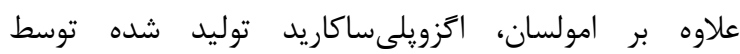
باكترىهاى دريايى، به شكل امولسيونهاى يايدار با تعدادى

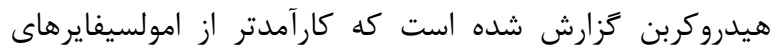

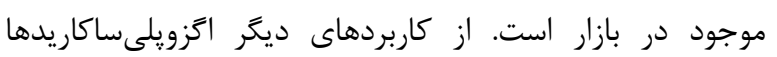
مىتوان به حذف فلزات سنخين اشاره كرد. سلولهاى متصل به

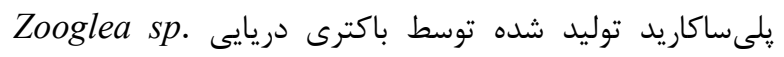

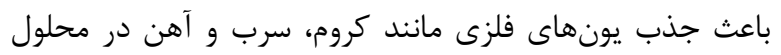
Enterobacter cloaceae مىشود. جذب فلزات سنگين توسن كزارش شده است (Iyer et al., 2004). علاوه بر اين، اتزويلىساكاريدها منبع خوبى از مونوساكاريدها هستند، برخى از هومو و هترويلىساكاريدهاى خارج سلولى آلى باكتريايى مواد اوليه براى به دست آوردن اجزاى مونوساكاريد غير

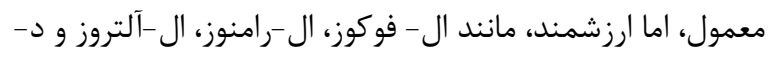
مانوز هستند. زيرا سنتز شيميايى يا استخراج آنها دشوار، كران و اغلب كم است. گونهاى Clavibacter، كلاوان كه غنى از

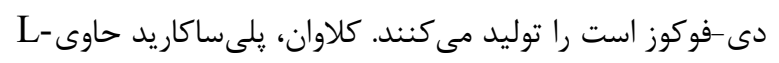
فوكوز، در جلو كيرى از تشكيل كلنى توسط سلولهاى تومور ريه، 


\section{REFERENCES}

Al-Dhabi, N.A., Esmail, G.A., Duraipandiyan, V., Arasu M.V. \& Salem-Bekhit, M. M. 2016. Isolation, identification and screening of antimicrobial thermophilic Streptomyces sp. Al-Dhabi-1 isolated from Tharban hot spring, Saudi Arabia. Extremophiles 20: 79-90.

Arifuzzaman, M., Khatun, M. \& Rahman. H. 2010. Isolation and screening of actinomycetes from Sundarbans soil for antibacterial activity. African J. Biotechnol. 9: 4615-4619.

Barka, E.A., Vatsa, P., Sanchez, L., Gaveau-Vaillant, N., Jacquard, C., Klenk, H.P., Clément, C., Ouhdouch, Y. \& van Wezel, G.P. 2016. Taxonomy, physiology, and natural products of actinobacteria. Microbiol. Mol. Biol. Rev. 80: 1-43.

Bikova, T. \& Treimanis. A. 2004. UV-absorbance of oxidized xylan and monocarboxyl cellulose in alkaline solutions. Carbohydr. Polym. 55: 315-322.

Castellane, T.C.L., Otoboni A.M.M.B. \& Lemos. E.G.d.M. 2015. Characterization of exopolysaccharides produced by rhizobia species. Rev. Bras. Cienc. Solo. 39: 1566-1575.

Ciszek-Lenda, M. 2011. Biological functions of exopolysaccharides from probiotic bacteria. Centr. Eur. J. Immunol. 36: 51-55.

Ghalem, B. R. 2017. Antioxidant and antimicrobial activities of exopolysaccharides from yoghurt starter. - Am. J. Chem. Biochem. Eng. 2: 35-39.

Goodfellow, M. \& Williams, S. 1983. Ecology of actinomycetes. Annu. Rev. Microbiol. 37: 189-216.

Hidalgo-Cantabrana, C., Sánchez, B. Milani, C., Ventura, M., Margolles A. \& Ruas-Madiedo. P. 2014. Genomic overview and biological functions of exopolysaccharide biosynthesis in Bifidobacterium spp. J. Appl. Environ. Microbiol. 80: 9-18.

Iyer, A., Mody K. \& Jha, B. 2004. Accumulation of hexavalent chromium by an exopolysaccharide producing marine Enterobacter cloaceae. Mar. Pollut. Bull. 49: 974-977.

Jia, S., Yu, H. Lin Y. \& Dai Y. 2007. Characterization of extracellular polysaccharides from Nostoc flagelliforme cells in liquid suspension culture. Biotechnol Bioprocess Eng. 12: 271-275.

Jeong, D., Kim, D.H., Kang, I.B., Kim, H., Song, K.Y., Kim, H.S. \& Seo K.H. 2017. Characterization and antibacterial activity of a novel exopolysaccharide produced by Lactobacillus kefiranofaciens DN1 isolated from kefir. Food Control 78: 436-442.

Jorgensen, J. 1993. Antimicrobial susceptibility testing of bacteria that grow aerobically. Infect. Dis. Clin. North. Am. 7: 393-409.

Kanamarlapudi, S.L.R.K. \& Muddada, S. 2017. Characterization of exopolysaccharide produced by Streptococcus thermophilus CC30. Biomed. Res. Int. 2017: 1-11.

Khalil, E.S., Abd Manap, M.Y., Mustafa, S., Alhelli, A. M. \& Shokryazdan., P. 2018. Probiotic properties of exopolysaccharide-producing Lactobacillus strains isolated from Tempoyak. Molecules 23: 398.

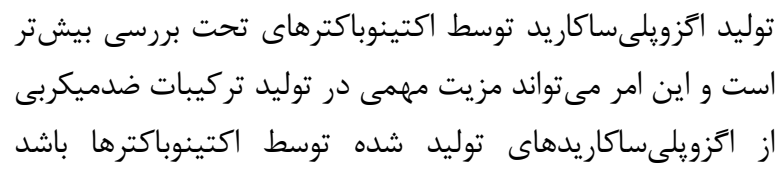
.(Jeong et al., 2017)

Promicromonospora sp. اخزويلمىساكاريد FT-IR طيف

حضور ساختار ريليمرى از كربوهيدرات را آشكار ساخت. So41

يك كشيدگى وسيع در طيف هيدروكسيل كربوهيدراتها است. حضور ييك جذبى در طيف منان دهنده حضور گروههاى متيل و متيلن است. همجنين باند جذبى در طيف

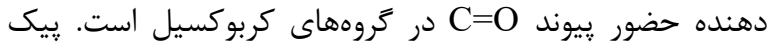
جذبى در طول موج له + ا نيز نشاندهنده حضور C-O-C ييوند كليكوزيدى است. بر اساس دادههاى به دست آمده از تحليل طيف FT-IR مىتوان ييشبينى كرد كه اگزويلىساكاريد سويه

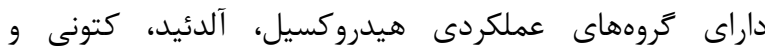
كليكوزيدى باشد (Suart, 2004).

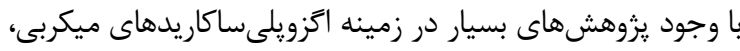
يزوهشهاى كمى در زمينه بررسى فعاليتهاى زيستى اخزويلى ساكاريدهاى بلهدست آمده از اكتينوباكترها انجام شده است، با توجه لئه به يتانسيل بالاى اكتينوباكترها در توليد انواع آنتى بيوتيكها

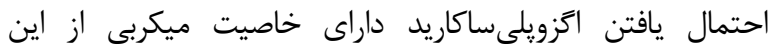
باكترىها بسيار بالا است. اين يزوهش برونئ براى اولين بار توانسته

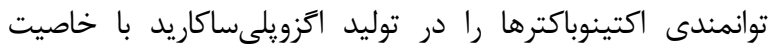
ضدميكربى نشان دهد. يروهش هاى بيشترى در دست دست انجام است تا

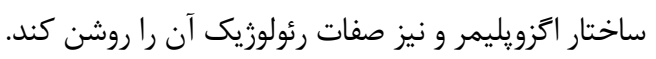
سياسخز ارى از زحمات خانم ليلا يرويزى و خانم فهميه محمدنيا در اجراى اين مطالعه سياسگزاريم. 
Kim, Y., Hong, J.W., Chung, Y.S., Kim, S.W., Cho, Y.W., Kim, J.H., Kim, B.J. \& Lee., E.J. 2014. Efficacy and safety of sustained-release recombinant human growth hormone in Korean adults with growth hormone deficiency. Yonsei Med. J. 55: 1042-1048.

Kumar, M.A., Anandapandian, K.T.K. \& Parthiban, K. 2011. Production and characterization of exopolysaccharides (EPS) from biofilm forming marine bacterium. Braz. Arch. Biol. Technol. 54: 259265.

Kumar, V., Bharti, A., Gusain, O. \& Bisht, G. S. 2010. An improved method for isolation of genomic DNA from filamentous actinomycetes. J. Sci. Engg. Tech. Mgt. 2: 10-13.

Lee, H.R., Kim, K.K. \& Whang, K.S. 2010. Isolation and phylogenetic characteristics of exopolysaccharide producing bacteria in a rhizosphere soil of Medicinal Herbs. Kor. J. Microbiol. 46: 278-285.

Lin, S.P., Calvar, I.L., Catchmark, J.M., Liu, J.R., Demirci A. \& Cheng, K.C. 2013. Biosynthesis, production and applications of bacterial cellulose. Cellulose 20: 219-2219.

Manivasagan, P., Venkatesan, J., Sivakumar, K. \& Kim, S.K. 2014. Pharmaceutically active secondary metabolites of marine actinobacteria. Microbiol. Res. 169: 262-278.
Moscovici, M. 2015. Present and future medical applications of microbial exopolysaccharides. Front Microbiol. 6: 1012.

Nwodo, U.U., Green, E. \& Okoh, A.I. 2012. Bacterial exopolysaccharides: functionality and prospects. Int. J. Mol. Sci. 13: 14002-14015.

Stach, E. \& Bull, A.T. 2005. Estimating and comparing the diversity of marine actinobacteria. Antonie van Leeuwenhoek 87: 3-9.

Suart, B. 2004. Infrared spectroscopy: Fundamental and applications. John Wiley \& Sons, pp: 137-166.

Suresh Kumar, A., Mody, K. \& Jha, B. 2007. Bacterial exopolysaccharides-a perception. J. Basic. Microbiol. 47: 103-117.

Vijayabaskar, P., Babinastarlin, S., Shankar, T., Sivakumar, T. \& Anandapandian, K. 2011. Quantification and characterization of exopolysaccharides from Bacillus subtilis (MTCC 121). Adv. Biol. Res. 5: 71-76.

Worthington, R.J. \& Melander, C. 2013. Combination approaches to combat multidrug-resistant bacteria. Trends Biotechnol. 31: 177-184.

Wu, M.H., Pan, T.M., Wu, Y.J., Chang, S.J., Chang, M.S. \& Hu., C.Y. 2010. Exopolysaccharide activities from probiotic bifidobacterium: Immunomodulatory effects (on J774A. 1 macrophages) and antimicrobial properties. Int. J. Food. Microbiol. 144: 104-110.

How to cite this article:

Tavanaeian, S., Hamedi, J. \& Haghighat, S. 2020. Introducing antimicrobial-exopolymer producing actinobacteria from soils of Iran. Nova Biologica Reperta 7: 55-63. (In Persian).

تواناييان، س.، حامدى، ج و حقيقت، س. وجب ا. معرفى اكتينوباكترهاى مولد اكزويليمرهاى داراى خاصيت ضدميكربى از خاكهاى ايران. يافتههاى نوين در

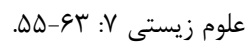

